\title{
Evaluation of in vitro anti-inflammatory activity of the spadix of Colocasia affinis
}

\author{
Vanlalhruaii*, C. Malsawmtluangi, H. Lalhlenmawia \\ Department of Pharmacy, Regional Institute of Paramedical and Nursing Sciences (RIPANS), Zeambawk 796017, India
}

\begin{abstract}
The methanolic extract of $C$. affinis was evaluated for its in-vitro anti-inflammatory activity by bovine serum albumin denaturation method, egg albumin denaturation method and protease inhibition method at different concentrations. Diclofenac sodium was used as the reference drug. The extract exhibits anti-inflammatory activity in a concentration-dependent manner. In bovine serum albumin denaturation method, the extract at concentrations of 100, 200,400,600,800, 1000 $\mu \mathrm{g} / \mathrm{ml}$ showed $25.49,28.43,31.37,37.25,41.17,48.03 \%$ inhibition respectively. In egg albumin denaturation method, the concentrations of 50,100,200,300,400, $500 \mu \mathrm{g} / \mathrm{ml}$ showed $5.3,9.89,28.12,32.8,43.2,52.8 \%$ inhibition respectively. In protease inhibition method the extract at concentration of 100, 200,300,400, 500 $\mu \mathrm{g} / \mathrm{ml}$ showed $8.87,19.32,28.56,43.96,59.92 \%$ inhibition respectively. Therefore, from the results it can be concluded that the methanolic extract of $C$. affinis possesses anti-inflammatory activity.
\end{abstract}

Keywords: Colocasia affinis, anti-inflammatory, protease inhibition, protein denaturation.

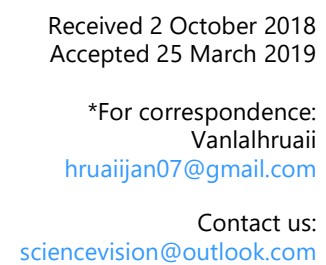

\section{Introduction}

Plants have a long history of improving human health and for curing various diseases. Plants play a major role in traditional systems of medicine for thousands of years and continue providing new remedies to mankind. ${ }^{1}$ Therefore, the research on plant is rising all over the world and there is a huge evidence showing massive potential of medicinal plants used in various traditional systems. ${ }^{2}$ Colocasia affinis, belonging to the family Araceae, is a broad leave and perennial herb with slightly pink petiole. It grows in an altitude below $900 \mathrm{~m}$. Flowers and fruits are mainly produced during June-August. It is found in Bangladesh, Tripura and Assam. In Mizoram, it is mainly found in new jhum land. In Mizo tradition, it is mainly consumed as dish after boiling with water. Traditionally, juice of the plant is used externally for snake bite. The leaf is also used for catching land leech from the body. ${ }^{3}$ The methanolic rhizome extract was reported to possess remarkable analgesic activity. ${ }^{4}$ The leaves and stolon of the plant were confirmed to have antioxidant properties. ${ }^{5}$ This study is carried out to screen the in vitro antiinflammatory activity of $C$. affinis.

Inflammation is a protective response of the body to tissue injury, microbial infection, allergy or chemical irritants. It is an important immune response which acts to remove harmful stimuli as well as initiates the healing of damaged tissue. The inflammatory response is characterized by redness, pain, swelling and heat. ${ }^{6}$ Non-steroidal and steroidal drugs were used for the treatment of inflammatory diseases. The non-steroidal anti-inflammatory drugs (NSAIDs) are the main drugs used for reducing the untoward consequences of inflammation and inhibit early steps in the biosynthesis pathway of prostaglandins by inhibition of COX enzymes. ${ }^{7}$ But NSAIDs cause unwanted effects like gastric injury and ulceration, renal injury and bronchospasm due to their non- selective inhibition of both isoforms of COX enzymes. ${ }^{8}$ Steroidal drugs also possess multiple side effects and their used as anti-inflammatory drugs is becoming highly controversial..$^{9}$ Therefore, 
development of newer and more potent antiinflammatory drug with lesser side effect is necessary.

\section{Materials and Methods}

\section{Chemicals and reagents}

Serum albumin (Himedia), cassein (Himedia), diclofenac sodium (Sigma-Aldrich), distilled water, disodium hydrogen phosphate (Merck), egg albumin, hydrochloric acid (Merck), perchloric acid (Merck), potassium dihydrogen phosphate (Loba Chemie), sodium chloride (SD Fine Chem.), Tris buffer, trypsin (Sigma-Aldrich) were all analytical grades.

\section{Collection of plant material}

Spadix of $C$. affinis was collected from the local market of Aizawl, Mizoram. It was dried under shade to remove moisture. It was ground to coarse powder. The plant specimen was authenticated at the Botanical Survey of India, Shillong (AP/ RIPANS/04).

\section{Extraction of plant material}

The dried and powdered materials of spadix of $C$. affinis were defatted with petroleum ether $\left(60-80^{\circ} \mathrm{C}\right)$ and then extracted with chloroform and methanol in a soxhlet apparatus. The extraction was carried out exhaustively and the solvents were recovered by simple distillation. The concentrated extracts were kept in refrigerator at $4^{\circ} \mathrm{C}$ for further use.

\section{Phytochemical studies}

The methanolic extract of $C$. affinis was screened for the presence of alkaloids, glycosides, fats and fixed oils, proteins, amino acids, saponins, tannins and flavonoids and aqueous extract for carbohydrates. ${ }^{10}$

\section{Evaluation of in vitro anti-inflammatory activity}

The in vitro anti-inflammatory activity was studied using bovine serum albumin denaturation method, egg albumin denaturation method and protease inhibition method.

\section{Bovine serum albumin (BSA) denaturation method}

Test solution $(0.5 \mathrm{ml})$ consists of $0.45 \mathrm{ml}$ of BSA ( $5 \% \mathrm{w} / \mathrm{v}$ aqueous solution) and $0.05 \mathrm{ml}$ of the test solution $(100,200,400,600,800$ and $1000 \mu \mathrm{g} / \mathrm{ml})$.
Test control solution $(0.5 \mathrm{ml})$ consist of $0.45 \mathrm{ml}$ of BSA ( $5 \% \mathrm{w} / \mathrm{v}$ aqueous solution) and $0.05 \mathrm{ml}$ of distilled water. Product control solution $(0.5 \mathrm{ml})$ consists of $0.45 \mathrm{ml}$ of distilled water and $0.05 \mathrm{ml}$ of test solution. Standard solution $(0.5 \mathrm{ml})$ consist of $0.45 \mathrm{ml}$ of BSA ( $5 \% \mathrm{w} / \mathrm{v}$ aqueous solution) and 0.05 $\mathrm{ml}$ of diclofenac sodium $(100,200,400,600,800$, $1000 \mu \mathrm{g} / \mathrm{ml}$ ). All the above solutions were adjusted to $\mathrm{pH} 6.3$ using $1 \mathrm{~N}$ Hydrochloric acid. The samples were incubated at $37^{\circ} \mathrm{C}$ for 20 minutes and the temperature was increased to keep the samples at $57^{\circ} \mathrm{C}$ for 3 minutes. After cooling, $2.5 \mathrm{ml}$ of phosphate-buffered saline was added to the above solutions. The absorbance was measured using UVvisible spectrophotometer at $416 \mathrm{~nm}$. The percentage inhibition of protein denaturation was calculated by the formula: ${ }^{11}$

Percentage inhibition (\%) =

100- Absorbance of control-Absorbance of sample $\times 100$ Absorbance of control

\section{Egg albumin denaturation method}

The reaction mixture $(5 \mathrm{ml})$ consist of $0.2 \mathrm{ml}$ of egg albumin (from fresh hen's egg), $2.8 \mathrm{ml}$ phosphate buffered saline $(\mathrm{pH} 6.4)$ and $2 \mathrm{ml}$ of varying concentration of plant extracts. Similar volume of double distilled water served as control. Then the mixtures were incubated at $37 \pm 2^{\circ} \mathrm{C}$ in an incubator for 15 minutes and then heated at $70^{\circ} \mathrm{C}$ for 5 minutes. After cooling, their absorbance was measured at $660 \mathrm{~nm}$ by using vehicle as blank. Diclofenac was used as reference drug and treated similarly for determination of absorbance. The Percentage inhibition of protein denaturation was calculated as follows: ${ }^{12}$

Percentage inhibition (\%) =

100- Absorbance of control-Absorbance of sample $\times 100$ Absorbance of control

\section{Protease inhibition assay}

The reaction mixture $(2 \mathrm{ml})$ was containing 0.06 $\mathrm{mg}$ trypsin, $1 \mathrm{ml} 20 \mathrm{mM}$ Tris buffer $(\mathrm{pH} \mathrm{7.4)}$ and 1 $\mathrm{ml}$ test sample of different concentration (100-500 $\mu \mathrm{g} / \mathrm{ml}$ ). The mixture was incubated at $37^{\circ} \mathrm{C}$ for $5 \mathrm{~min}$ and then $1 \mathrm{ml}$ of $0.8 \%(\mathrm{w} / \mathrm{v})$ casein was added. The mixture was incubated for an additional $20 \mathrm{~min} .2 \mathrm{ml}$ of $70 \%$ perchloric acid was added to arrest the reaction. Cloudy suspension was centrifuged and the absorbance of the supernatant was read at $210 \mathrm{~nm}$ against buffer as blank. The percentage inhibition of protease inhibitory activity was calculated: ${ }^{13}$

Percentage inhibition (\%) =

100- Absorbance of control-Absorbance of sample $\times 100$ Absorbance of control 
Table 1 | Results of preliminary phytochemical screening of the methanol extract of $C$. affinis.

\begin{tabular}{clc}
\hline $\begin{array}{c}\text { Sl } \\
\text { No. }\end{array}$ & Phytochemical test & $\begin{array}{c}\text { Presence or } \\
\text { absence }\end{array}$ \\
\hline 1 & Alkaloids & - \\
\hline 2 & Flavonoids & $\mathbf{+}$ \\
\hline 3 & Proteins and amino acids & - \\
\hline 4 & Fats and fixed oils & - \\
\hline 5 & Tannins & + \\
\hline 6 & Steroids and triterpenoids & - \\
\hline 7 & Glycosides & - \\
\hline 8 & Saponins & - \\
\hline 9 & Carbohydrates (aqueous) & + \\
\hline
\end{tabular}

Table 3 | Effect of methanol extract of $C$. affinis on egg albumin denaturation.

\begin{tabular}{|c|c|c|}
\hline \multirow{2}{*}{$\begin{array}{c}\text { Concentration } \\
(\mu \mathrm{g} / \mathrm{ml})\end{array}$} & \multicolumn{2}{|c|}{ Percent inhibition (\%) } \\
\hline & Standard & Extract \\
\hline 50 & 12.5 & 5.3 \\
\hline 100 & 21.3 & 9.89 \\
\hline 200 & 50 & 28.12 \\
\hline 300 & 60.61 & 32.8 \\
\hline 400 & 72.91 & 43.2 \\
\hline 500 & 86.34 & 52.8 \\
\hline
\end{tabular}

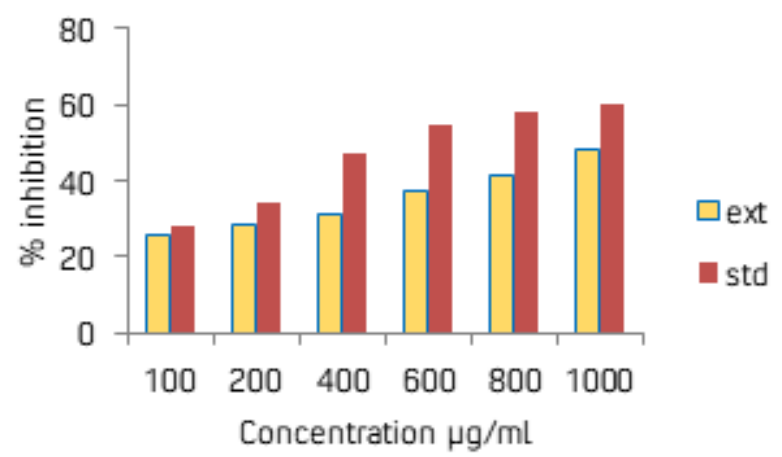

Figure 1 | Effect of methanol extract of $C$. affinis on BSA denaturation.

\section{Results}

\section{Phytochemical screening}

The phytochemical screening of methanolic extract of C. affinis showed the presence of flavonoids and tannins and aqueous extract showed the presence of carbohydrates as shown in Table 1.

\section{In vitro anti-inflammatory activity}

In in vitro anti-inflammatory activity by bovine
Table 2 | Effect of methanol extract of $C$. affinis on BSA denaturation.

\begin{tabular}{ccc}
\hline $\begin{array}{c}\text { Concentration } \\
(\boldsymbol{\mu g} / \mathbf{m l})\end{array}$ & \multicolumn{2}{c}{ Percent inhibition (\%) } \\
\hline 100 & Standard & Extract \\
\hline 200 & 28.21 & 25.49 \\
\hline 400 & 34.43 & 28.43 \\
\hline 600 & 47.05 & 31.37 \\
\hline 800 & 54.90 & 37.25 \\
\hline 1000 & 57.84 & 41.17 \\
\hline
\end{tabular}

Table 4 | Effect of methanol extract of $C$. affinis on protease inhibition assay.

\begin{tabular}{ccc}
\hline $\begin{array}{c}\text { Concentration } \\
(\boldsymbol{\mu g} / \mathrm{ml})\end{array}$ & \multicolumn{2}{c}{ Percent inhibition (\%) } \\
Standard & Extract \\
\hline 100 & 31.12 & 8.87 \\
\hline 200 & 50.21 & 19.32 \\
\hline 300 & 60.57 & 28.56 \\
\hline 400 & 65.06 & 43.95 \\
\hline 500 & 75.84 & 59.92 \\
\hline
\end{tabular}

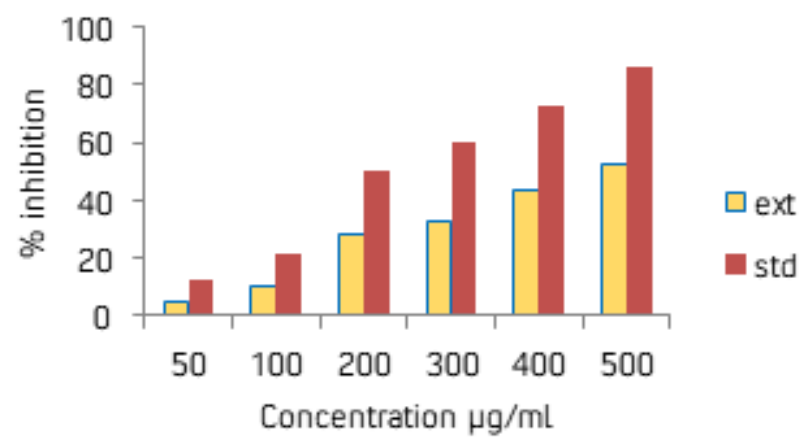

Figure 2 | Effect of methanol extract of $C$. affinis on egg albumin denaturation.

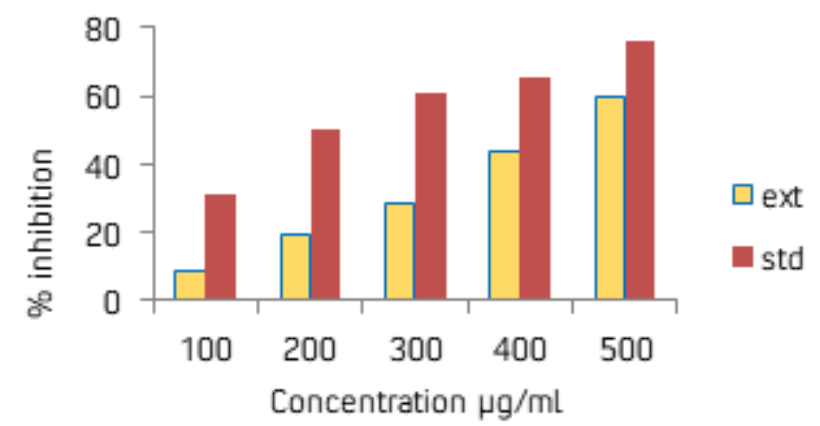

Figure 3 | Effect of methanol extract of $C$. affinis on protease inhibition assay. 
serum albumin denaturation method the extract at the concentrations of 100,200,400,600, 800 and $10000 \mu \mathrm{g} / \mathrm{ml}$ showed 25.49, 28.43, 31.37, 37.25, $41.17,48.03 \%$ inhibition of denaturation of bovine serum whereas, standard diclofenac at 100, 200, 400, 600,800 and $1000 \mu \mathrm{g} / \mathrm{ml}$ showed 28.21, 34.43, 47.05, $54.90,57.84,59.80 \%$ inhibition of denaturation of bovine serum (Table 2 and Fig. 1). IC $C_{50}$ value for the standard (diclofenac) was found to be $2.53 \mu \mathrm{g} / \mathrm{ml}$ whereas $\mathrm{IC}_{50}$ value for the extract was $4.82 \mu \mathrm{g} / \mathrm{ml}$.

In vitro anti-inflammatory activity by egg albumin denaturation method the extract at concentrations of $50,100,200,300,400$ and $500 \mu / \mathrm{ml}$ showed 5.3 , $9.89,28.12,32.8,43.2,52.8 \%$ inhibition of egg albumin denaturation whereas, standard diclofenac at $50,100,200,300,400$ and $500 \mu / \mathrm{ml}$ showed 12.5, $21.3,50,60.61,72.91,86.34 \%$ inhibition of egg albumin denaturation (Table 3 and Fig. 2). $I C_{50}$ value for the standard was $3.94 \mu \mathrm{g} / \mathrm{ml}$ and the $\mathrm{IC}_{50}$ value for the extract was $6.78 \mu \mathrm{g} / \mathrm{ml}$.

\section{Protease inhibition assay}

The methanolic extract of $C$. affinis at concentration of $100,200,300,400,500 \mu \mathrm{g} / \mathrm{ml}$ showed 8.87, 19.32, 28.56, 43.96, 59.92\% inhibition of protease and diclofenac at the same concentration showed 31.12, 50.21, 60.57, 65.06, $75.84 \%$ inhibition of protease (Table 4 and Fig. 3). The $I C_{50}$ value for the standard was found to be 2.37 $\mu \mathrm{g} / \mathrm{ml}$ and the $\mathrm{IC}_{50}$ value for the extract was $4.41 \mu \mathrm{g} /$ $\mathrm{ml}$.

\section{Discussion}

The preliminary phytochemical screening showed the presence of flavonoids and tannins in methanolic extract and carbohydrates in aqueous extract. In the in vitro anti-inflammatory activity screening, it was observed that the methanolic extract of $C$. affinis showed significant activity. The activity was shown in concentration-dependent manner, i.e. with the increase in concentration the activity was also increased. Denaturation of protein is one of the causes of inflammation. The production of auto antigens in inflammation disease may be due to in vivo denaturation of proteins. The mechanism of denaturation possibly involves alteration in electrostatic, hydrogen, hydrophobic and disulphide bonding. ${ }^{14}$ A number of anti-inflammatory drugs have shown the ability to inhibit thermally induced denaturation. ${ }^{17}$ Inhibition of denaturation of protein by the extract of C. affinis is possibly a contributing factor for its anti-inflammatory activity. Neutrophils are the group of white blood cells known to be a rich source of proteinase enzyme which carries in their lysosomal granules or vesicles contain many serine proteinases. It was reported that leukocytes proteinase plays a major role in the development of tissue damage during inflammatory reactions and efficient level of protection was provided by proteinase inhibitors. $^{15}$ The methanolic extract exhibit anti-proteinase activity at various concentrations as shown in Table 4. The antiinflammatory activity of $C$. affinis may be due to the presence of flavonoids. Flavonoids are reported to inhibit prostaglandin synthase specifically endoperoxidase and able to produce antiinflammatory effects. ${ }^{16}$ The therapeutic application of flavonoids on inflammation have been reported. $^{18,19}$

\section{Conclusion}

The result of the in-vitro studies showed that the extract possesses anti-inflammatory activity which may be due to the presence of flavonoids. However further studies involving the isolation and purification of the chemical constituents of the plant and the investigations in the biochemical pathways may result in the development of a potent antiinflammatory agent with a low toxicity.

\section{Acknowledgement}

The authors are thankful to the Department of Pharmacy, RIPANS, for providing all necessary facilities to complete this study.

\section{References}

1. Heinrich, M., Barnes, J., Gibbons, S., Williamson, E.M. (2004). Fundamentals of Pharmacognosy and Phytotherapy. Churchill Livingstone, Elsevier Science Ltd., UK, pp. 203-234.

2. Prajapati, R., Kalariya, M., Umbarkar, R., Parmar, S., Sheth, N. (2011). Calocasia esculenta: A potent indigenous plant. International Journal of Nutrition, Pharmacology, Neurological Diseases 1, 90-97.

3. Sawmliana, M. (2013). The Book of Mizoram Plants (includes wild animals, birds, etc.). P. Zakhuma, Aizawl, Mizoram, pp. 16 \& 255.

4. Sarwar, S., Biva, I.J., Ahmed, T., Ahmed, M.I., Rahman, M.A. (2010). Phytochemical screening and analgesic activities of two bangladeshi medicinal plants: Diospyrosperegrina and Alocasia fornicata. Khulna University Studies 10,179-184.

5. Mandal, P., Mishra, T.K., Singh, I.D. (2010). Antioxidant activity in the extracts of two edible aroids. Indian Journal of Pharmaceutical Sciences 201, 8-105.

6. Medzhitov, R. (2008). Origin and physiological roles of inflammation. Nature 454, 428-435.

7. Albert., Zundrof, D., Dingerman, I., Muller, D., Steinhilber, W.E \& Werz, D. (2002). Hiperforin is a 
dual inhibitor of cyclooxygenase-1 and 5lipoxygenas. Biochemical Pharmacology 64, 17671775.

8. Tapiero., Ba, H., Couvreur, G.N \& Tew, P. (2002). Polyunsaturated fatty acids (PUF A) and eicosanoids in human health and pathologies. Biomedicine \& Pharmacotherapy 56, 215-222.

9. Worm, V.D., Beukelman, E., Berg, C.J., Kores, A.J.J., Labadie, B.H \& Dijk, R.P.V. (2001). Effects of methoxylation of apocynin and analogs on the inhibition of reactive oxygen species production by stimulated human neutrophils. European Journal of Pharmacology 433, 225-230.

10. Kokate, C.K., Purohit, A.P \& Gokhale, S.B. (2013). Pharmacognosy. Nirali Prakashan, Shivaji Nagar, Pune, pp. 21-26.

11. Kar, B., Kumar, R.B.S., Karmakar, I., Dola, N., Bala, A., Mazumder, U.K \& Hadar, P.K. (2012). Antioxidant and in vitro anti-inflammatory activities of Mimusops elengi leaves. Asian Pacific Journal of Tropical Biomedicine 2, 976-980.

12. Sangeetha, G., Vidhya, R. (2016). In-vitro antiinflammatory activity of different parts of Pedalium murex (L.) International Journal of Herbal Medicine 4,31-36.

13. Oyedepo, O.O., Femurewa, A.J. (1995). Antiprotease and membrane stabilizing activities of extracts of Fagra zanthoxiloides, Olax subscorpioides and Tetrapleura tetraptera. International Journal of Pharmacognosy 33, 65-69.
14. Bagad, Y.M., Umarkar, A.R., Tatiya, A.U \& Surana, S.J. (2011). Investigation of analgesic and anti-inflammatory activity of Bridelia airyshawii (Euphorbiaceae). Journal of Pharmacy Research 4, 1326-1332.

15. Grant, N.H., Alburn, H.E., Kryzanauskas, C. (1970). Stabilization of serum albumin by antiinflammatory drugs. Biochemical Pharmacology 19, 715-722.

16. Sachin, S.S., Archana, R.J \& Manoj (2010). In vitro antioxidant and anti-inflammatory activity of methanol extract of Oxalis Corniculata Linn. International Journal of Pharmacy and Pharmaceutical Sciences 2, 146-155.

17. Panda, B.B., Gaur, K, Kori, M.L., Tyagi, L.K., Nema, R.K., Sharma, C.S., Jain A.K. (2009). AntiInflammatory and Analgesic Activity of Jatropha gossypifolia in Experimental Animal Models. Global Journal of Pharmacology 3, 1-5.

18. Middleton, E., Kandaswami, C., Theoharides, T.C. (2000). The effects of plant flavonoids on mammalian cells: implications for inflammation, heart disease and cancer. Pharmacological Review $52,673-751$

19. Havsteen, B.H. (2002). The biochemistry and medical significance of the flavonoids. Pharmacology \& Therapeutics 96, 67-202. 